Historic, Archive Document

Do not assume content reflects current scientific knowledge, policies, or practices. 
PAUL H. DAVEY VICE PRESIDENT THE DAVEY TREE EXPERT CO

LESTER C. LOVETT PAST PRESIDENT

EASTERN NURSERYMAN'S ASSOCIATION DR. ROBERT T. MORRIS NEW YORK SURGEON, AUTHOR, DEAN OF THE NORTHERN NUT GROWERS' ASSOCIATION

BOARD OF ADVISORS

F. W. LUERIING

THE MILWAUKEE JOURNAL

PERCIVAL S. RIDSDALE

MANAGING EDITOR

NATURE MAGAZINE
EVERETT G. GRIGGS, 2ND ST. PAUL AND TACOMA LUMBER CO TACOMA, WASH.

ELLEN EDDY SHAW BROOKLYN BOTANIC GARDEN

ERNEST THOMPSON SETON FORMER CHIEF SCOUT BOY SCOUTS OF AMERICA

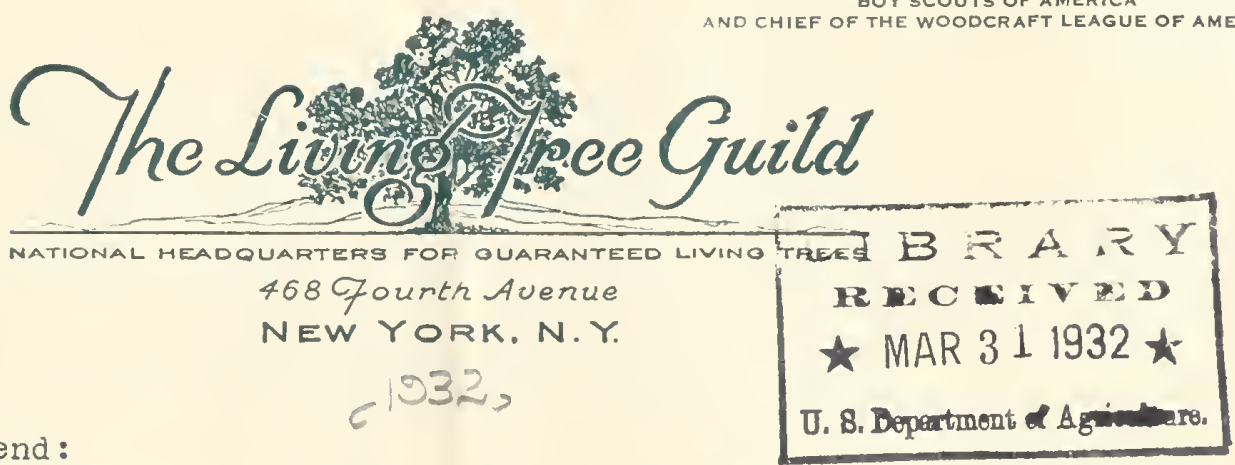

Dear Friend:

See what is chosen by the IIVING TREE GUILD for you this year: TREES - PERENNIALS - SHRUBS - HEDGES VINES.

You can comb the whole country - the finest sources for plants and trees - and we believe you will not find any better qualities or lower prices with a full guarantee.

We are genuinely interested in the results that you get from your efforts. We want to make sure that your investment is good. Every shipment from the LIVING TREE GUILD brings clear, simple instructions.

Above all, we want to bring you a message of good cheer. There is something very comforting in making friends with trees and plants. We are reminded of those beautiful words of Robert Browning, when he said:

world."

$$
\text { "God's in His Heaven - All's right with the }
$$

Sincerely yours, this tree to our friends. See inside page. 


\section{HARDY PERENNALS*}

MIPEIIAT JAPANESE IRIS-LookS like the best of the orchids. No better Japanese Iris anywhere.

BAILLAIRDA (Blanliet Flower)-Flowers with red centers, with rings of crimson, maroon, orange or vermil lion. Also topped with orange or lémon.

KOREAN CHIRYSANTHEMUM - Two years ago we sold this exceptional variety for $\$ 1.00$ per plant. Brilliant claret pink colored flowers until late Fall. Vely hardy. Don't miss having these in your garden.

HARDY PILOX-The great panicles of bloom make the Hardy Phlox one of the most showy of all objects on the lawn during the summer nonths.

DOCBLE IOLIYHOCKS - Extra fine flower stalks, often grow to over five feet in height. A glory for the back fence line.

HARDY CYRISANTIHEMEMS - When other flowers are entering on their winter's rest, these Hardy Chrysanthemums are in their prime.

COLUMBINES-Can be used in full sunlight or partial shade. Graceful airy tlowers.

LARISPIR - Flower stalks produce blooms of various shades of blue, the stalks sometimes over five feet in height.

I3.ABY'S BIEATH-One of the most popular old-fashioned perennials.

HARDY STVETT SCENTWD IUPINES -Various colors of flowers - blue mauve and pink, reaching majestically upward from long stems.

ORIENTAL POPPY-Flowers from five to seven inches across on tall stems. A gorgcous variety.

SHASTA DAISY-One of the finest of Luther Burbank's productions. Pure white flowers, frequently $21 \%$ or 3 inches in diameter.

\section{PRTCES OF HARDY TPERTENTALS}

BOX A .............20 plants (1 of each of the above)

$\$ 3.55$

BOX B .............40 plants ( 2 of each of the above)

BOX C..............80 plants (4 of each of the above)

$\$ 12.95$

If you want special selections-more of one varicty and less of another-indicate your choice on order form. But be sure total number of plants amounts to 20 or 40 , or 80 plants.

(Less than 20 plants, per plant 30 cents.)

(IIardy Perennials, since they are fowers, do not come under the one year guarantee on oll Guild Trees.)
CLOVE SCENTED PINKS - Delightfully sweet scented flowers (like carnations). Early summer flowering in great abundance, more sparingly in mid and late summer. Shades of pink predominace in great range of colors.

CANTERBLIT BELLS-Profusion of bell-shaped blue and pink flowers through July and August.

COREOPSIS-The best of the hardy yellow flowers for mass effect. Blooms constantly from June to frost.

HHBISCUS (or Marshmallow) - Enormous blossoms, sometimes 8 to 10 inches in diameter, white and pink: produced from early August to frost.

PAINTED DAISIES (or Pyrethrum)"These might be called "Aristocrats" of the flower garden because of their refined beauty. Most attractive foliage helps accentuate their refinement.

LOOSE STRIFE (Lysimachia) - Long dense spikes of pure white flowers. During the last half of the summer.

DROPMORE (Anchusa)-Will grow to four or five feet, with delightful gentian blue flowers an inch or more across. During the first half of the summer.

ORANGE SUN FLOWER (Heliopsis Pitcherianus) - Grows from two to three feet, producing deep golden yellow flowers freely through the summer.

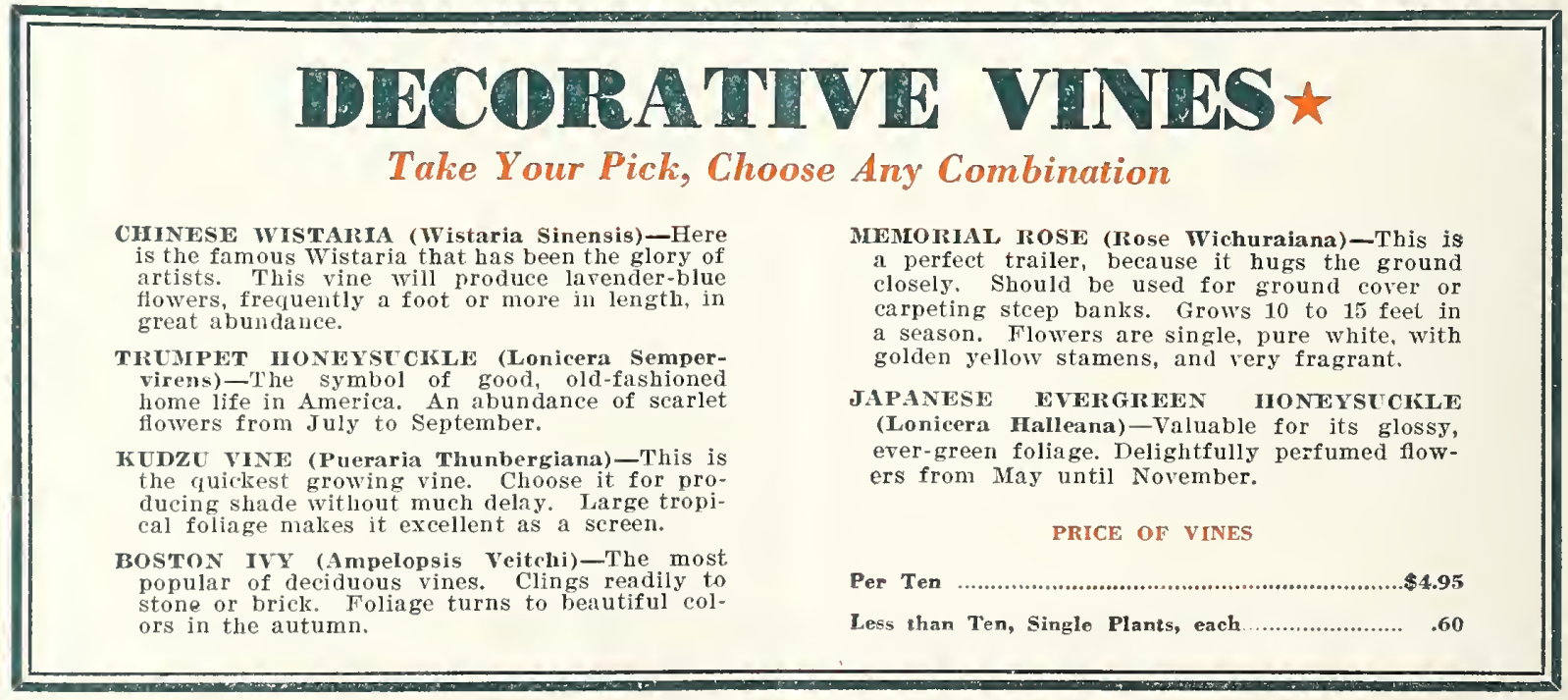




\section{GEOIREE WASHINGTON Bi-Centennial Cherry Tree?}

All over the country this year they are celcbrating the 200th Anniversary of the birth of George Washington. The heart of every patriot is stirred.

To commemorate this historical event, the Living Tree Guild dedicates to George Washington one of the most beautiful cultivated Cherry Trees in America. This tree is none other than the Governor Wood. We have been guided in this choice by one of the country's leading horticulturists, who was engaged to find the finest variety Cherry Tree for all-round domestic use.

This tree now dedicated to George Washington is one of the rarest and best. Every friend of

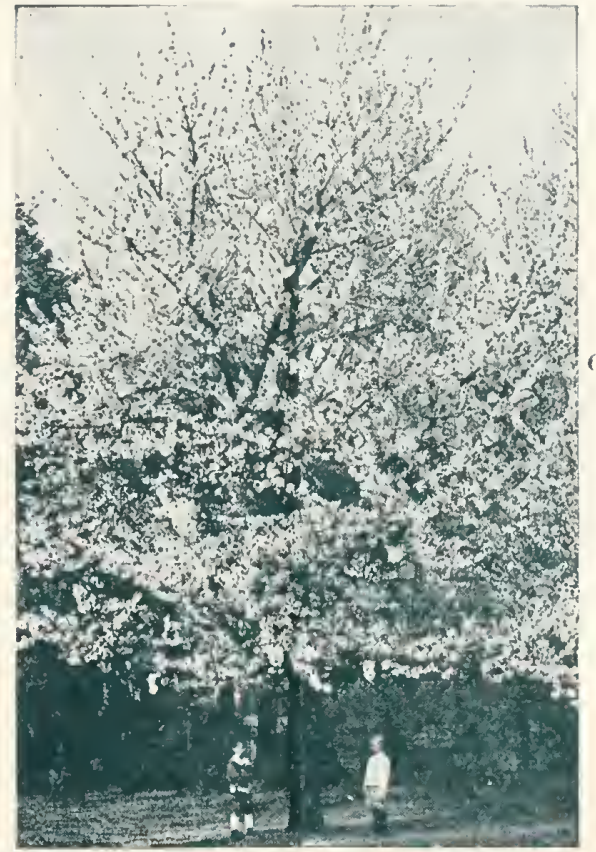

Beautiful flowers! the Living Tree Guild who owns this tree will delight in it.

'This is a sweet cherry. The fruit is a beautiful red and amber. It is luscious. 'The tree virtually produces a shower of large cherries, fairly bursting with juice. A wholesome and healthy food. Full of invigorating vitamines, while the tree itself gives a hospitable sliade, especially for the small yard.

Do not confuse this cultivated cherry tree with the wild cherry. The latter is a breeding place for tent caterpillars and in many ways unsatisfactory. This sweet cherry is lovely and wholesome in every way.

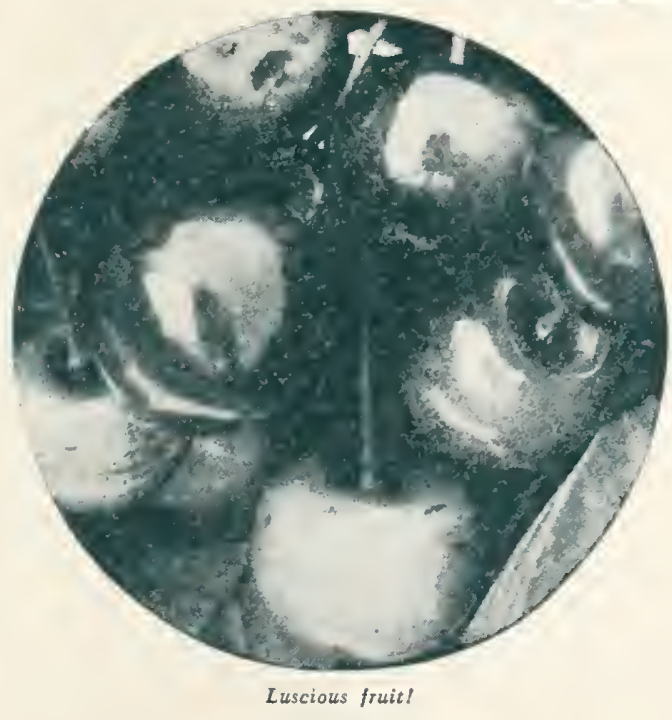

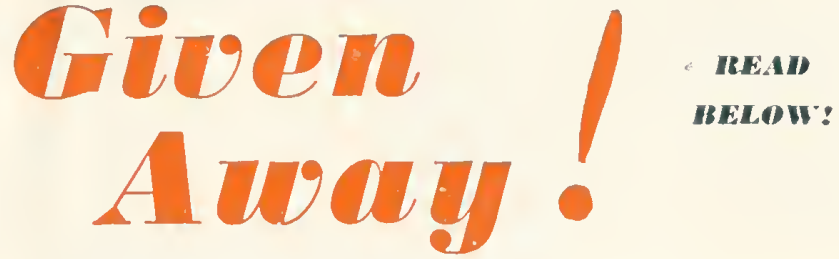

This Bicentennial Cherry Tree, dedicated to George Washington, will be sent without cost to friends of the Living 'Tree Guild this year. It will be included with our compliments in every shipment of $\$ 5.00 \mathrm{or}$ more of those trees, peremnials, shrubs, vines and hedges which are marked in this folder with a star. Look for the stars! Remember that you will receive the George Washington Bi-centennial Cherry Tree without added cost.

LOOK FOR THE STARS! 


\section{Momey In Walnuts}

\section{NEW WAY TO FAVE CROPS OF BIGGER NUTS MUCH QUICKER}

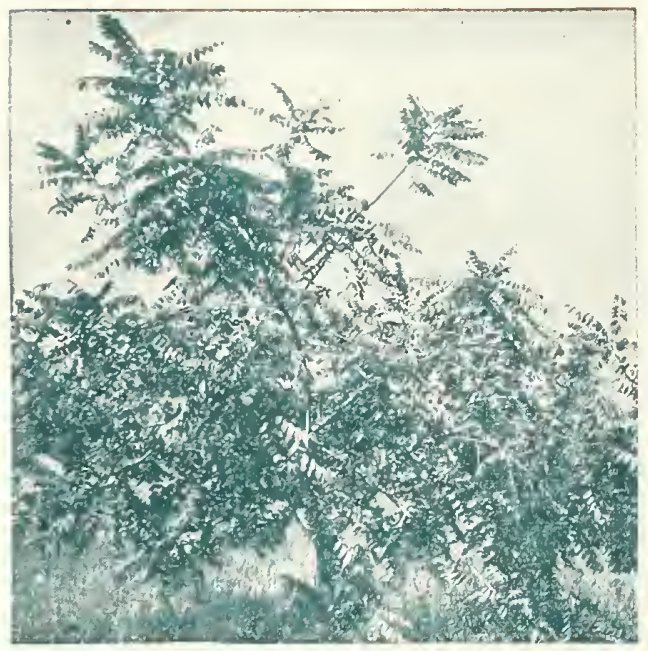

Black II alnut tree raised from Pedigree, In its fifth year from planting this tree is bearing 300 large nuts. These may le used in biscuits, salads, turkey dressing. ice cream, candy, and as a picnic specially.

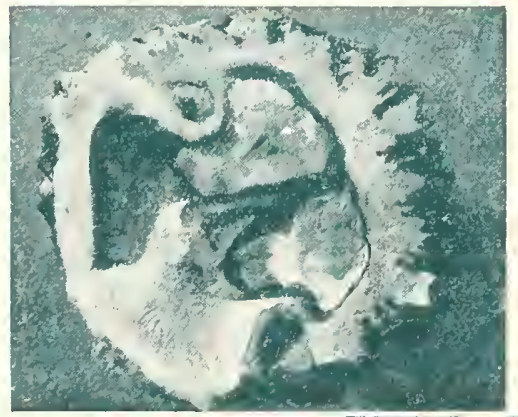

\section{E. DITINAIRY}

IBLACE

WAI.NUT

LEFT

Hard nut to crack on account of its extremely thick shell. Undersized kernels, almosi improsible to extraci whole. This is the kind of nut that is raised after many years from seedlings and wild trees. All the delicious flavor is re. tained in the Pedigreed nuts.

\section{PEIDIGR EEID}

BLACK

WALNUT'

RIGHT

Note how thin the shell is compared to the pic lure above, Very easy to crack. The large kernel of delicious meat literall $\gamma$ tumbles out whole. Th black walnut is the only nut that does not lose it lavor in cooking.

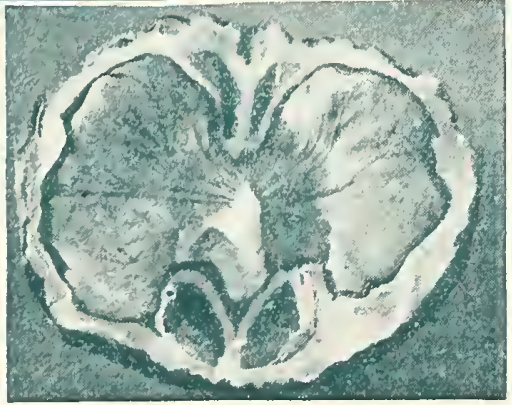

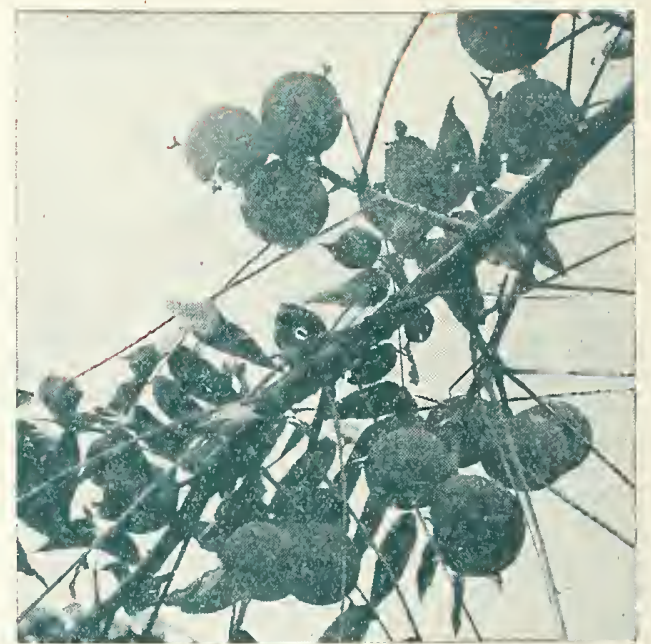

The picture shows nuts grawing on a tree in ils fith year from planting. Sometimes big nuts appear in the second or third year! Each Guild Black Talnut Pedigree is numbered and registered in the home affice. A metal tag with the tree's serial number accompanies each Pedigree.

\section{PRICES}

Black Walnut Pedigrees, 4-5 foot, grafted, registered Pedigrees $\$ 3.90$ each

Hazel Hybrids and Filbertst, 3-5 foot, grafted 2.25 each

Nut Tree Fertilizer 1.00 per $5 \mathrm{lbs}$.

tThese trees are shipped together for cross-pollination in the approximate ratio of 2 Hazel Hybrids to 1 Filbert. Order total number of these trees desired and leave the combination to us.

\section{PLANTING NOTES}

Fertilizer: Figure on one pound per tree, minimum order 5 lbs.

Spacing: Your main crop of Black Walnuts should be spaced 40-50 feet. You can put the Hazels and Filberts between the Black Walnuts. If you use only the Hazels and Filberts, figure 20-25 foot spacing. The Black Walnuts will make by far the most valuable planting. We recommend Hazels and Filberts only for a delicious intermediate crop.

Instructions for planting accompany shipment. 


\section{America's Fastest Growing Shade Tree}

\section{The Siberiam Elm $*$}

(Ulmus Pumila-

Hardy Northern Strain)

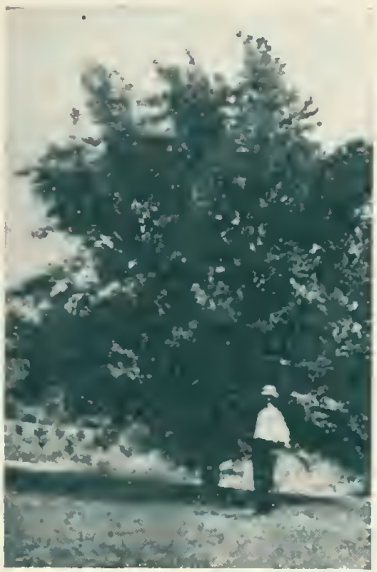

This picture was taken at College Park, Maryland, and shores a fine specimen. When this trec was planted it had a girth of $21 / 2$ inches. Now it measures oier 36 inch girth and over 32-foot spread after 5 years growth.

friends who planted these SIBERIAN ELMS four years ago now point with pride to them-higher than the roof of the house!

\section{U. S. Department of Agriculture Says:}

"It is hardy and has proved valuable under a greater variety of climate and soil conditions than any tree yet introduced."

\section{PRICES ON SIBERIAN ELMS}

$$
2.3 \mathrm{ft} . \quad 5 \mathrm{ft} . \quad 6-8 \mathrm{ft} . \quad 10-12 \mathrm{ft} \text {. }
$$

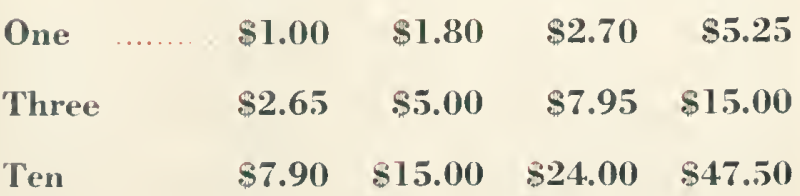

This beautiful tree develthe maple, but grows almost twice as fast as the maple or the American After the first year, four customary growing schedthis wonderfu IAN ELM is hardy. It kind of soil. It will stand timate. re which variety of SIBERIAN ELMS.

This is the fourth year has sponsored the SIBER g this time it has become one of the most popular trees in the country. Today, our 童

.




\section{CHOICEVARIETY (1) TREES}

\section{Seldom Secn and of Rare Beauty}

JAP. ANESE WETPING PINK FLOWTRED CHERTY-A brilliant importation from the orient. This is the tree selected by the landscape alehitects of the beautiful Lincoln Memorial at Washington, I). C., and now helps to make that spot one of the nost chalming shrines of America. Long slender branches appear like a waterfall of pink flowers.

(With fize-foot stems and one-year heads when delivered)

Each

$\$ 6.00$

Three

17.50

Per dozen

65.00

PRTYS NEITPORT-An exceptionally fine, improved strain of Purple-leaved Plum. Retains its rich purple foliage throughout summer and fall. Foliage is perhaps even more attractive than that of the rare River's Purple Beech. (Size when delivered, 3-4 ft.)

Each

Three 18.00

Per dozen

ELI FLOWERING CRABAPPLE-While this tree was under
ingestigation, a nember of the Guild Board of Advisors neceived the following repolt: "A very beautiful crab, large red flowers, the tree is loaded with cherry-colored fruit at this time of vear, and as beautiful as auy tree can be

(Size when delivered, 3-4 ft.)

Each $\$ 2.00$

Three 5.75

Per dozen 18.00

DOCBLE RED FLOWETING PEACII-A tree which blooms very early in the Spring, affording a most welcome sight after a loug winter. Very gorgeous blossoms about one inch in diancter appearing in large clusters. Houble red flowers like big roses. Semi-dwarf in growth.

Size when delivered, $3-4 \mathrm{ft}$.)

Each

Three

Per dozen

PINA FLOWERING DOGWOOD (Flor. Rubra)-A beautiful variety of llowering Dogwood. Heretofore rather scarce in quantity and even now not too plentiful. Bears bright rosy jink flowers, lincommended for a beatiful lann tres. (Size when delicered, $2.3 \mathrm{ft}$.)

$\$ 3.95$

Each

Three

36.00

Per dozen

\section{SPECIAL?}

JAPANESE IBLOD LEAF MAPLE (Grafted specimens) - Inarf in lobit, lieautiful blood led leaves from early spring to late fall. The genuine bluod leaf maple so decolative for a spceinen lawn tree. 2 to $21 / 2$

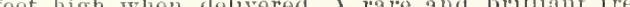

Each_\$7.50 Three__\$21.00 Dozen__\$79.20

\section{EVER GRERNS}

\section{for garden backgrounds and foundation planting}

MEIIICAN ARBOR VITAE-2 to $3 \mathrm{ft}$. When delivered. Will make a tall dense pyramid of deep green, lacy foliage. Endures shearing well and is excellent as a screen or hedge plant.

GLOBE AIBOR VITAE-11/2 ft. when delivered. A lovely, compact natural globe which will not exceed four feet in height.

CANADIAN HEMLOCI-2 to $3 \mathrm{ft}$. when delivered. Especially luardy for northern climates. Recommended for locations in partial shade, Feathery fresh green foliage-that makes a graceful individual tree, or can be trained for a fine hedge.

DOUGLAS FIR-2 to $3 \mathrm{ft}$, when delivered. One of the most valuable of the lofty trees. lyark green foliage, reminiscent of the deep forest. Excellent for a large lawn tree.

BOXWOOD (Burus Sempervirens) $\mathbf{- 1}$ to $1 \frac{1}{2} \mathrm{ft}$. high. Exquisite. Beautifully modelled, compact-with rolling sides across which play lights and shadows. Extremely hardy. These Box are $100 \%$ perfect. 12 to 18 inches when delivered. Upstanding, aristocratic and symmetrical.

PFITZIER'S ,JUNIPER-18 to 24 inch spread when delivered. Will make a gorgeous decoration like an explosion of green. Very hardy. While it will grow to 6 or 8 feet it can easily be trimmed and lept within any limits.

GOIDEN RETINOSPORA-The tips of its foliage are a bright golden hue. 2 to $3 \mathrm{ft}$. when delireled. The Retinosporas are among the most colorful and exquisite of the evergreens. Vigorous-but should not be planted in extremely severe clinates.

GREIEN RETINOSPORA-A decorative evergreen for foundation planting. 2 to $3 \mathrm{ft}$. When delivered-will grow vigorously and is easily trimmed.

BICE RETINOSPORA-Distinct and arresting with dense silver-blue foliage, of a feathery, billowy appearance. 2 to $21 / 2 \mathrm{ft}$. when delivered.

You can select all of one kind, or any desired combination.

Four of the above trees

For less than four, per tree

\section{RHODODENDRONS! $\star$}

\section{Special Hylbrid Straim}

An unusually fine strain of hybrid rhododendrons for our fricnds. Rhododendrons are gaining in popularity because they are green the year round and produce large multi-colored flowers during June and July.

These hybrid rhododendrons are descended from selected stock. If pedigrees were recorded the ancestors of these heautiful plants would be on the blue list.

These rhododendrons should be planted in acid soil, frue of lime. Need plenty of water and protection from winter sun. Leaf mould mulching is especially good. Color's of flowers cannot be determined in advance. The pedigree of this family, how.

ever, assures you of a magnifi-

rent assortment of colors, 10-

16 inches when delivered.

Each plant

$\$ 2.00$

Ten plants 18.00 


\section{$62.61 \mathrm{ORDE} \mathbb{R}^{11922}$ F ORM \\ Mail to \\ THE LIVING TREE GUILD \\ National Headquarters for Guaranteed Living Trees}

468 Fourth Avenue (at 31st Street), New York, N. Y.

On the dotted line beside the variety write the number of plants or trees of that variety that you wish. Shipnents will be nude at the proper time for planting.

\section{HARDY PERENNIALS $\star$}

Imperial Japanese Iris

Gaillardia

Korean Chrysanthemum

Hardy Phlox

Double Hollyhocks

Hardy Chrysanthemums

Columbines

Larkspur

Baby's Breath

Hardy Sweet Scented Lupines

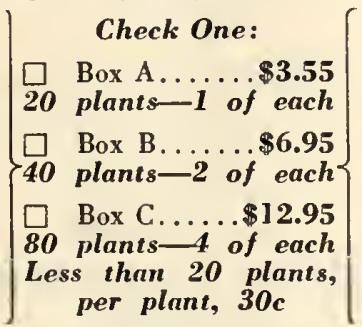

Oriental Poppy

Shasta Daisy

Clove Scented Pinks

Canterbury Bells

Coreopsis

Hibiscus

Painted Daisies

Loose Strife

Dropmore

Orange Sun

Flower

\section{CHOICE VARIETIES}

Japanese Weeping Pink Flowered Cherry (one tree $\$ 6.00$; three $\$ 17.50$; dozen $\$ 65.00$ )

Prunus Newport (one tree $\$ 2.00$; three $\$ 5.75$; dozen $\$ 18.00$ )

Eli Flowering Crabapple (one tree $\$ 2.00$; three $\$ 5.75$; dozen $\$ 18.00$ )

Double Red Flowering Peach (one tree $\$ 2.00$; three $\$ 5.75$; dozen $\$ 18.00$ )

Pink Flowering Dogwood (one tree $\$ 3.95$; three $\$ 10.75$; dozen $\$ 36.00$ )

\section{SPECIAL!}

Japanese Blood Leaf Maple (one tree \$7.50; three \$21.00; dozen \$79.20)

\section{SELECTED EVERGREENS}

American Arbor Vitae

Globe Arbor Vitae

Canadian Hemlock

Douglas Fir

Boxwood

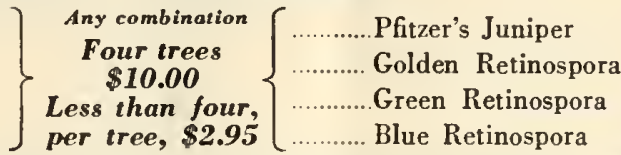

\section{RHODODENDRONS $\star$}

One Plant........\$2.00

Ten-Plants:-......\$18.00

\section{NUT TREES}

Black Walnut Pedigrees, 4.5 foot, grafted, (\$3.90 each)

Hazel Hybrids and Filberts $\neq, 3-5$ foot, grafted, $(\$ 2.25 \text { each })^{\text {. }}$

lbs. Nut Tree Fertilizer ( $\$ 1.00$ per 5 lbs.)

¥These trees shipped together for cross-pollination in the approximate ratio of 2 Hazel Hybrids to I Filbert. Order total number of these trees desired and leave the combination to us.

\section{SIBERIAN ELMS $\star$}

Siberian Elm, $2-3 \mathrm{ft}$. high (one tree $\$ 1.00$; three trees $\$ 2.65$; ten trees $\$ 7.90$ )

Siberian Elm, 5- ft. high (one tree $\$ 1.30 ;$ three trees $\$ 5.00$; ten trees $\$ 15.00$ )

Siberian Elm, 6-8 ft. high (one tree $\$ 2.70$; three trees $\$ 7.95$; ten trees \$24.00)

Siberian Elm, $10.12 \mathrm{ft}$. high (one tree $\$ 5.25$; three trees $\$ 15.00$; ten trees $\$ 47.50$ )

\section{SHADE TREES $\star$}

Norway Maple

Weeping Willow

Lombardy Poplar

Oriental Plane Tree

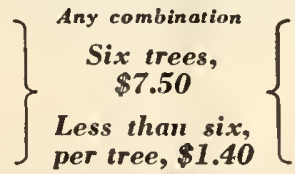

(OVER) 


\section{HEDGES $\star$}

Japanese Rose.......

.per dozen $\$ 1.25$

per dozen $\$ 1.25$

per hundred

Japanese Barberry.... per dozen $\$ .75$ per hundred

California Privet...... per dozen $\$ 1.75$

Genuine Boxwood .... Each $\$ 1.00$.... per dozen per hundred per hundred

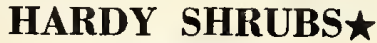

Butterfly Shrub

Hardy Hydrangea

Purple Lilac

Red Weigela

Red Twig Dogwood

Mock Orange

Marie LeGraye

Rubra de Marley

Charles X

Michel Buchner

Mme. Cassimer Perrier
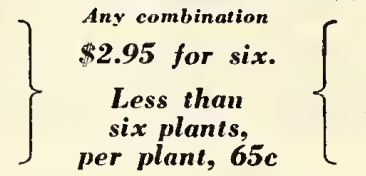

Bush Honeysuckle

Bridal Wreath

Golden Bell

Japanese Snowball

Hydrangea

Rosa Multiflora

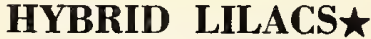

\section{BUMPER EVERGREENS}

Engelmann Blue Spruce

Scotch Pine

White Spruce

Norway Spruce
Any combination

Three plants, $\$ 4.00$

Six plants, $\$ 7.50$

Ten plants, $\$ 12.00$

Less than three, per plant, \$1.50

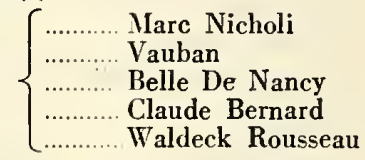

Marc Nicholi

Belle De Nancy

Claude Bernard

.

.

(a)




\section{H A R D Y \\ SHIU⿴囗十 *}

for filling bare corners with masses of flowers

BUTTERFLX SHRCB (Buddleia Magnifica) -This beautiful shrub begins to flower early in August, and continues in profuse bloom until frost. The long panicles of flowers resemble lilacs in color and shape. In rugged climate this lovely bush should be protected by a mulch in winter. It takes its name from the fact that butterflies are almost always hovering about this shrub. $1 \frac{1 / 2}{2}$ to 2 feet when delivered. Will grow to 6 feet or more.

HARDY IIYDRANGEA (Hydrangea Pan iculata frandiflora)-Showy blooms, pure white, turning pink. $1 \frac{1 / 2}{2}$ to 2 fect wlien delivered.

PCIPLE LILAC (talI) -The shrub our grandmothers gloried in. 18 to 24 inches when delivered.

RED WEIGELA (Weigela Fra Ruthke)Deep girnet-red flowers in great abundance throughout the sunmer and fall. 18 to $2 t$ inches when delivered.

† ED TWIG DOGWOOD (Cornus Siberica) -Especially desirable for winter effect, the brilliant red bark showing up in splendid contrast with frab surroundings. 18 to $2 t$ inches when delivered.

IOCK ORANGE (Philadelphus)-The oldfashioned Syringa of our grandmother's garlen. Attains great height with age. is to $2 t$ inches when delivered.

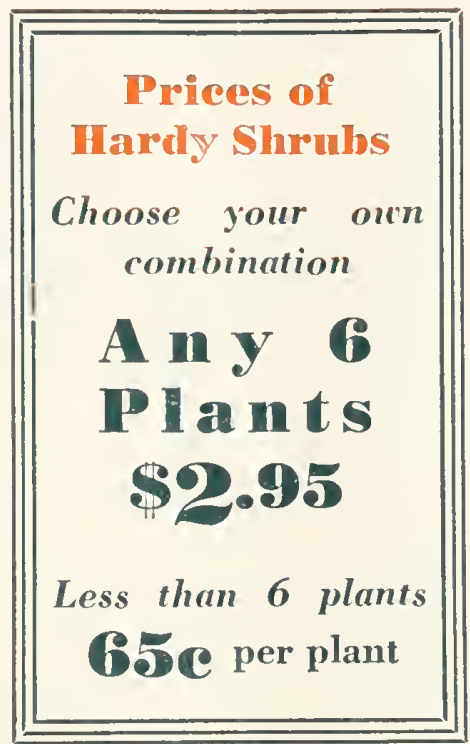

\# These Shrubs are best for adverse city conditions. Ezcry city home can have a touch of nature-even though there is congestion and dusty atmosphere.
IITSH HONEYSLCKLE-If you want birds around your home grounds plant this wonderful shrub. Its early winter red fruit is a magnet to the songsters. 18 to $2 \pm$ iuches when delivered.

IBRIOAL WIEATII (Spirea Van IFoutei) Absolutely hardy and the joy of every novice in gardening. Thousands of pure white hlossoms completely cover every bush. 18 to 24 inches when delivered.

tGOLIDE IELL (Forsythia)-The first herald of spring flowers. Brauches gloriously hurdened with yellow flowers beforc the foliage comes out. These branches can readily be cut and the golden sunsine that they radiate brought into the louse. Morcover, Golden Eell is extremely liardy and flourishes under almost any condition. 18 to 24 inches when delivered. It will grow into a ten-foot shrub. Cut. tings of Golden Fell will hloom indoors in mid-winter.

JAPANESE SNOWBALL (Virburnum Pli(atum)-Dense clusters of pure white flowers in grcat profusion. Late spring aud early summer. 18 to 24 inches.

II TIRANGEA (Aborescens Grandiflora) This erect shrul, from four to cight feet high is popularly called. "Hills of snow" because of its pure wite flowers, froin late June to late August. 18 to $2 t$ inches.

IROSA MIITIFLORA-Qunatities of loright red berries during the fall follow liuge clusters of white flowers in the early summer. I double cffect! 15 to 21 inches.

\section{HYI I ID LILACS! *}

\section{for a Remarkable Adventure}

These rarietles will fascinate the person who wants to grow something unusual. With these Hybrid Lilacs you can have in bloom, a few weeks after plauting. clusters of gorgeous varied colored flowers. Will surely bloom the first year, and note the colors.

MARIE LeGRANE-Pure white flowers, medium size. Very beautiful.

RIBRA de MAILEY - Lilac colored flowers toucleer with blue. Single, with large, full clusters.

CHARLES X-Large purple flowers. A rigorous grower.

MICHEL BLCHNER-Large, double clear lilac, shaded pink on inner petals.

MuE. CAssimer PERIIER - Very large, creamy white, double flowers.

MARC NiCIIOLI-A double, bluish-pink lilac.
VAIBAx-Dclicate maure pink. Extra double blossoms. A very appealing, softly insinuating flower.

BELLE De NANCY-Vigorous, freely blooming. Color, bright pink with white centers. One of the earliest and best.

CLAIDE BERNAID-A bright gray lilac, marked with bluish lavender. Quick growing.

WMLDECK ROUSSEAC - Soft, pinkish amethyst, slightly darker in the center. Long branching clusters of medium-sized flowers.

All the above plants 2-3 ft. in beight when delivered.

They are wonderfully hardy and very fast growers.
Each
$\$ 1.50$
Three
4.00
Sir
7.50
Ten
12.00 


\section{HUMPERTRES}

\section{Here's a Way to Revel in Evergireen Trees}

BUMPER EVERGREENS for the garden are a rare experience! Pick out different kinds of Evergreens and watch them develop. An Evergreen garden is one of the best investments you can make. In size, maturity and transplanting, BUMPER TREES are the equal of specimen trees which sell at a much higher price. The difference is in the method of cultivation, which saves labor costs. These trees are exceptionally sturdy, the foliage is glistening, moist and green. They will bring you a great amount of joy and profit. BUMPER TREES that will be sent to you are THE HARDIEST STOCK IN AMERICA. They are just right for increasing in value. They are sent

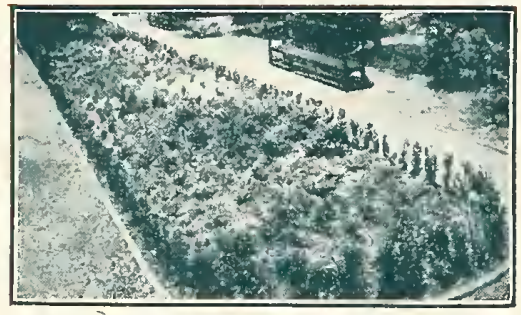

Garden of little evergreens at entrance to Country Life Press, on Long Island. at the exact time when their greatest growth and value is about to take place. They are bursting with life! Here is an experience in trees that you can have at slight cost, with every assurance of success. Ten trecs may be planted in a few square feet of space.

\section{THERE ARE NINE VARIETIES}

Make your own choice but be sure the total comes to 10 trees, 25 trees, or 100 trees-any combination.

Engelmann Blue Spruce (5 yrs) 9-12 in.

Scotch Pine ( 5 yrs) 18-24 in.

White Spruce (6.yrs) 10-16 in.

Norway Spruce (6 yrs) - 12-18 in.

Mugho Pine $(6 \mathrm{yr}$ s) 6-10 in.

Austrian Pine (5 yrs)_10-16 in.

American Arbor Vitae (5 yrs) _... 6-10 in.

Red Pine (6 yrs) 12-18 in.
PRICES

$\begin{array}{rr}10 \text { trees } & \$ 3.95 \text { delivered } \\ 25 \text { trees } & 9.50 \text { delivered } \\ 100 \text { trees } & 35.00 \text { delivered }\end{array}$

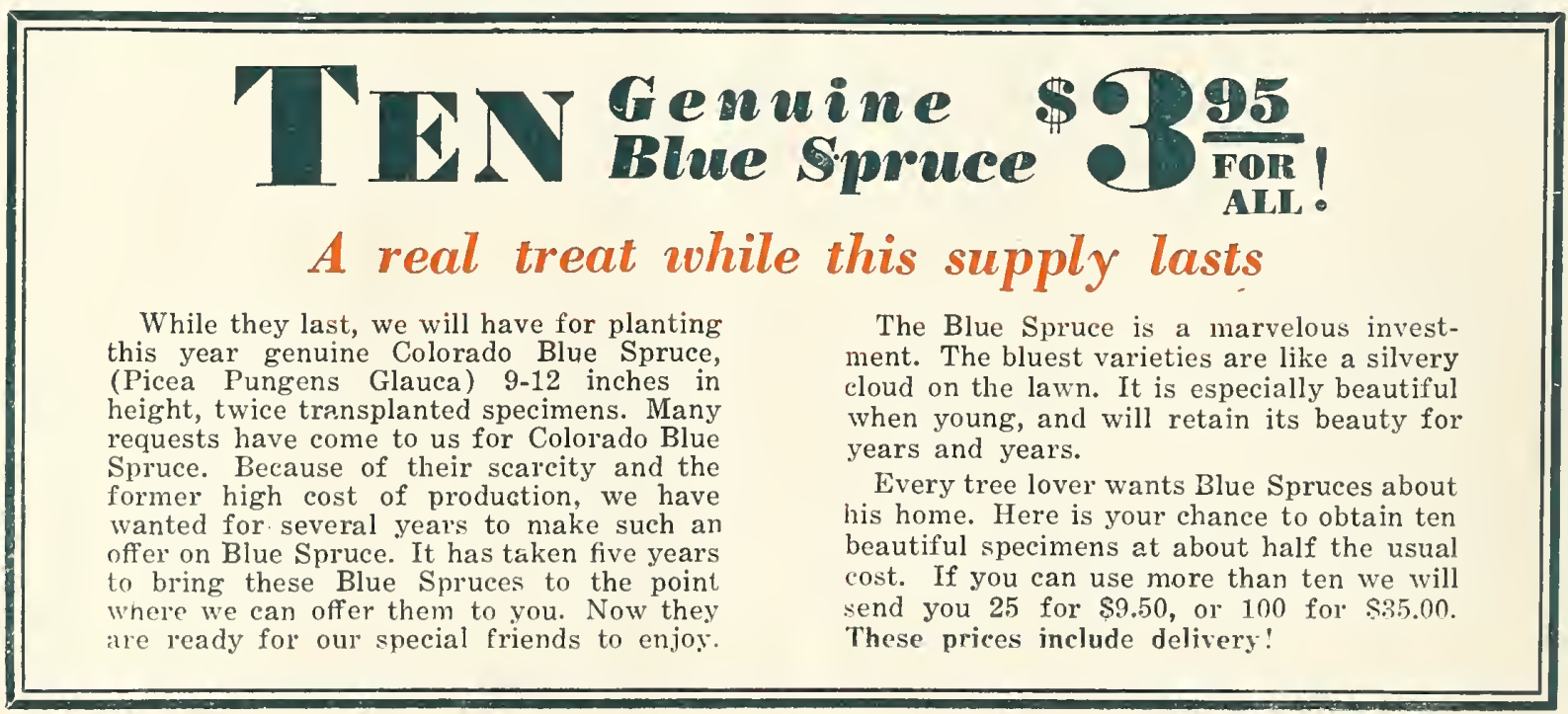

